\title{
Corrigendum to "CD206+ Cell Number Differentiates Influenza A (H1N1)pdm09 from Seasonal Influenza A Virus in Fatal Cases"
}

\author{
Heidi G. Rodriguez-Ramirez ${ }^{\mathbb{D}},{ }^{1}$ Mario C. Salinas-Carmona, ${ }^{1}$ Oralia Barboza-Quintana, ${ }^{2}$ \\ Americo Melo-de la Garza, ${ }^{2}$ Luis Angel Ceceñas-Falcon, ${ }^{2}$ Lilia M. Rangel-Martinez, ${ }^{3}$ \\ and Adrian G. Rosas-Taraco $\mathbb{D}^{1}$ \\ ${ }^{1}$ Department of Immunology, School of Medicine and University Hospital, Universidad Autonoma de Nuevo Leon (UANL), \\ Gonzalitos 235 Norte, Mitras Centro, 64460 Monterrey, NL, Mexico \\ ${ }^{2}$ Servicio de AnatomiaPatologica y Citopatologia, School of Medicine and University Hospital, Universidad Autonoma de Nuevo \\ Leon (UANL), Monterrey, NL, Mexico \\ ${ }^{3}$ Departamento de AnatomiaPatologica, Instituto Mexicano del Seguro Social (IMSS), HGZ No. 6, San Nicolas de los Garza, \\ NL, Mexico
}

Correspondence should be addressed to Adrian G. Rosas-Taraco; adrian.rosastr@uanl.edu.mx

Received 19 August 2020; Accepted 19 August 2020; Published 11 September 2020

Copyright (c) 2020 Heidi G. Rodriguez-Ramirez et al. This is an open access article distributed under the Creative Commons Attribution License, which permits unrestricted use, distribution, and reproduction in any medium, provided the original work is properly cited.

In the article titled "CD206+ Cell Number Differentiates Influenza A (H1N1)pdm09 from Seasonal Influenza A Virus in Fatal Cases" [1], there was an error in Figure 3 as raised on PubPeer [2], where the first image representing IL-17was inadvertently duplicated as the first image representing TNF- $\alpha$ but displaced upwards. The corrected figure, as approved by the editorial board, is shown below. 


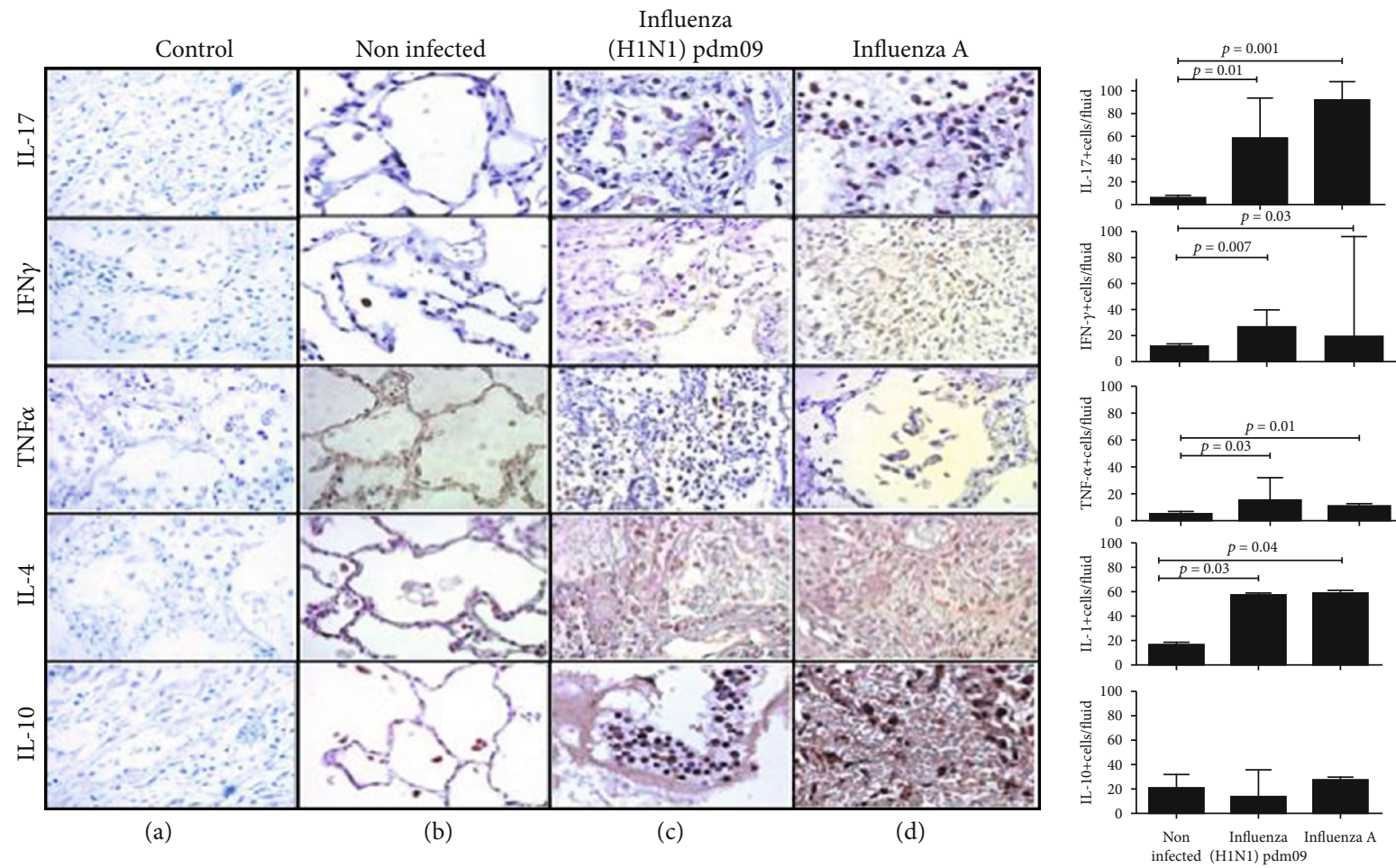

FIGURE 3: Predominant inflammatory environment cytokines were detected in influenza groups. High levels of IL-4, IL-17, IFN- $\gamma$, and TNF- $\alpha$ were found in lung from influenza A infected patients; meanwhile, significant differences were found in IL-10 levels $(\times 40)$.

\section{References}

[1] H. G. Rodriguez-Ramirez, M. C. Salinas-Carmona, O. BarbozaQuintana et al., "CD206+ cell number differentiates influenza A (H1N1)pdm09 from seasonal influenza A virus in fatal cases," Mediators of Inflammation, vol. 2014, Article ID 921054, 8 pages, 2014.

[2] Peer 1, "CD206+ Cell Number Differentiates Influenza A (H1N1)pdm09 from Seasonal Influenza A Virus in Fatal Cases," 2014, https://pubpeer.com/publications/ 85C260708041ACA8A6488B57A926A3. 